\title{
Outdoor air pollution, climatic changes and allergic bronchial
} asthma

\author{
G. D'Amato, G. Liccardi, M. D'Amato, M. Cazzola
}

\begin{abstract}
Outdoor air pollution, climatic changes and allergic bronchial asthma. G. D'Amato, G. Liccardi, M.D'Amato, M. Cazzola. (C) ERS Journals Ltd 2002.

ABSTRACT: Both the prevalence and severity of respiratory allergic diseases such as bronchial asthma have increased in recent years. Among the factors implicated in this "epidemic" are indoor and outdoor airborne pollutants. Urbanisation with its high levels of vehicle emissions and Westernised lifestyle parallels the increase in respiratory allergy in most industrialised countries, and people who live in urban areas tend to be more affected by the disease than those of rural areas. In atopic subjects, exposure to air pollution increases airway responsiveness to aeroallergens. Pollen is a good model with which to study the interrelationship between air pollution and respiratory allergic diseases. Biological aerosols carrying antigenic proteins, such as pollen grains or plantderived paucimicronic components, can produce allergic symptoms. By adhering to the surface of these airborne allergenic agents, air pollutants could modify their antigenic properties. Several factors influence this interaction, i.e., type of air pollutant, plant species, nutrient balance, climatic factors, degree of airway sensitisation and hyperresponsiveness of exposed subjects. However, the airway mucosal damage and the impaired mucociliary clearance induced by air pollution may facilitate the penetration and the access of inhaled allergens to the cells of the immune system, and so promote airway sensitisation. As a consequence, an enhanced immunoglobulin E-mediated response to aeroallergens and enhanced airway inflammation favoured by air pollution could account for the increasing prevalence of allergic respiratory diseases in urban areas.
\end{abstract}

Eur Respir J 2002; 20: 763-776.
Division of Pneumology and Allergology and Dept of Chest Diseases, Azienda Ospedaliera ad Alta Specialità "A.Cardarelli", Napoli, Italy.

Correspondence: G. D'Amato

Division of Pneumology and Allergology, Hospital A.Cardarelli

Via Rione Sirignano 10

80121 Napoli

Italy

Fax: 390817473331

E-mail: gdamato@qubisoft.it

Keywords: Air pollution

bronchial asthma

pollen allergy

respiratory allergy

urban air pollution

Received: March 182002

Accepted: March 192002
It was Plinius the Younger [1] who provided the first description of a fatal respiratory disorder induced by natural air pollution. "Innitens servolis duobus assurrexit et statim concidit, ut ego colligo, crassiore caligine spiritu obstructo, clausoque stomacho qui illi natura invalidus et angustus et frequenter aestuans erat" (Leaning on two servants, he brought himself upright and immediately collapsed again, I suppose because his breathing was affected by the dense fog that obstructed his airways that were of a weak nature, narrow and subject to inflammation). The patient was Plinius the Elder, scientist and head of the Roman fleet, who had moved from Naples to Pompei to observe the eruption of Mount Vesuvius and to help population of Pompei in the year ad73. Plinius the Younger describes the clouds of airborne matter issuing from the Vesuvius. The term "inflammation of the airways" was used for the first time in this letter by Plinius the Younger, and in defining the airways of Plinius the Elder as being "of a weak nature", the author stressed the patient's constitutional predisposition.

A wealth of evidence suggests that allergic respiratory diseases such as bronchial asthma have become more common worldwide in recent years [2-5]; in parallel, much aetiological and pathogenic research has been carried out in the attempt to determine why. While the interplay between genetic and environmental factors in the development of allergic respiratory diseases remains a subject of investigation, it appears there is a link between the increase in the prevalence of allergic airway diseases and the increase in air pollution. Several studies have shown the adverse effects of ambient air pollution on respiratory health [5-11],

Previous articles in this series: No. 1: Baldacci S, Omenaas E, Oryszcyn MP. Allergy markers in respiratory epidemiology. Eur Respir $J$ 2001; 17: 773-790. No. 2: Antó JM, Vermeire P, Vestbo J, Sunyer J. Epidemiology of chronic obstructive pulmonary disease. Eur Respir J 2001; 17: 982-994. No 3: Cuvelier A, Muir J-F. Noninvasive ventilation and obstructive lung diseases. Eur Respir J 2001; 17: 1271-1281. No 4: Wysocki M, Antonelli M. Noninvasive mechanical ventilation in acute hypoxaemic respiratory falure. Eur Respir J 2001; 18: 209-220. No 5: Østerlind K. Chemotherapy in small cell lung cancer. Eur Respir J 2001; 18: 1026-1043. No 6: Jaakkola M.S. Environmental tobacco smoke and helth in the elderly. Eur Respir J 2002; 19: 172-181. No 7: Hollings N. Shaw P. Diagnostic imaging of lung cancer. Eur Respir J 2002; 19: 772-742. No 8: Künzli N. The public health relevance of air pollution abatement. Eur Respir J 2002; 20: 198-209. 
and exposure to components of air pollution enhances the airway response to inhaled allergens in susceptible subjects. Indeed, in most industrialised countries, people who live in urban areas tend to be more affected by allergic respiratory diseases than those of rural areas [12, 13].

Bronchial asthma is characterised by airway inflammation, airway hyperresponsiveness to a variety of specific and nonspecific stimuli, and reversible airway obstruction with the appearance of respiratory symptoms such as dyspnoea, chest tightness, wheezing and cough. Even though the pathogenesis of bronchial asthma is not completely understood, it is evident that this clinical condition has a multifactorial aetiology.

It is important to note that an individual's response to air pollution depends on the source and components of the pollution, as well as on climatic agents. Indeed, some air pollution-related episodes of asthma exacerbation are due to climatic factors that favour the accumulation of air pollutants at ground level [14] and some cities are perennially affected by black smog caused by motor vehicles.

There is evidence that living near roads with high levels of car traffic is associated with impaired respiratory health. In fact, road traffic with its gaseous and particulate emissions is currently, and is likely to remain, the main contributor to air pollution in most urban settings [15-17]. A study from the Netherlands [18] demonstrated that children with atopy and bronchial hyperresponsiveness are at risk of increased symptoms during episodes of air pollution. Respiratory symptoms in children with bronchial hyperresponsiveness and high levels of serum total immunoglobulin (Ig) E increased by as much as $139 \%$ for every $100 \mu \mathrm{g} \cdot \mathrm{m}^{-3}$ increase in particulate matter (PM). It should be noted, however, that the study did not take account of the airborne allergen content, which is a potential confounding factor.

Air pollution is associated convincingly with many signs of asthma exacerbation, e.g. increased bronchial hyperresponsiveness, visits to emergency departments, hospital admissions, increased medication use [19-21]. Moreover, time-series data clearly show that trafficrelated air pollution in urban areas has adverse effects on mortality from respiratory and cardiovascular disease [22-29]. In a study of six USA cities, after adjusting for smoking, the mortality rate ratio increased in the most polluted areas compared with the least polluted city [25]. This observation, which initially met with some scepticism, has been confirmed in a wide range of settings and in different countries.

The most abundant air pollutants in urban areas with high levels of vehicle traffic are respirable particules with an aerodynamic diameter of $<10 \mu \mathrm{m}$ (PM10), nitrogen dioxide $\left(\mathrm{NO}_{2}\right)$ and ozone $\left(\mathrm{O}_{3}\right)$. The effects of air pollutants on lung function depend largely on the type of pollutant and its environmental concentration, the duration of pollutant exposure and the total ventilation of exposed persons. Aeroallergens, such as those derived from pollen grains and fungal spores, lead to bronchial obstruction in predisposed allergic subjects and pollen is widely used to study the interrelationship between air pollution and respiratory atopic diseases [29-33].
Airborne pollen grains, paucimicronic plant debris [34] and pollen grains ruptured during thunderstorms [35-37] can cause allergy symptoms in predisposed subjects. They also interact with other airborne contaminants in producing these effects. It has been suggested that air pollutants promote airway sensitisation by modulating the allergenicity of airborne allergens [31-38]. There is also evidence that the airway mucosal damage and impaired mucociliary clearance induced by air pollution may facilitate the penetration and access of inhaled allergens to the cells of the immune system [38-40]. Moreover, patients affected by asthma are frequently affected by rhinitis and, thus, breathe through the mouth, bypassing the nasal scrabbing mechanisms and so facilitating the penetration of pollutants and aeroallergens in the lower airways [41, 42].

\section{Urban outdoor air pollutants and plant-derived airborne allergens implicated in allergic respiratory diseases}

Although the nature and concentration of outdoor pollutants vary from one area to another, the most abundant pollutants in the atmosphere of urban areas are $\mathrm{NO}_{2}, \mathrm{O}_{3}$ and respirable PM. Sulphur dioxide $\left(\mathrm{SO}_{2}\right)$ is an additional concern in industrial areas. Aeroallergens are carried and delivered by fungal spores or by plant-derived particles (pollen, paucimicronic components of a vegetable nature and in some cases soybean dust etc.).

\section{Ozone}

$\mathrm{O}_{3}$ is the most important factor in the so-called "summer smog", since it is the main component of photochemical oxidants and probably accounts for up to $90 \%$ of total oxidant levels in cities that enjoy a mild sunny climate, such as those of the Mediterranean area and California, USA, etc. $\mathrm{O}_{3}$ is generated at ground level by photochemical reactions involving ultraviolet radiations on atmospheric mixtures of $\mathrm{NO}_{2}$ and hydrocarbons derived from vehicle emissions. $\mathrm{O}_{3}$ trends depend not only on substrate supply $\left(\mathrm{NO}_{2}\right.$ emitted by cars), but also on sunny weather that favours the transformation of $\mathrm{NO}_{2}$ into $\mathrm{O}_{3}$, thereby, producing photochemical smog. Current safety standards for $\mathrm{O}_{3}$ levels are exceeded frequently in most Mediterranean countries. Approximately $40-60 \%$ of inhaled $\mathrm{O}_{3}$ is absorbed in the nasal airways, the remainder reaching the lower airways.

Exposure to increased atmospheric levels of $\mathrm{O}_{3}$ causes decrements in lung function, increased airway reactivity to nonspecific and specific bronchoconstrictor agents and is related to an increased risk of asthma exacerbation in susceptible asthmatic patients [43-48]. Atmospheric levels of $\mathrm{O}_{3}$ and $\mathrm{NO}_{2}$ have been linked to increases in respiratory morbidity and in hospital admissions for asthma in children and adults [20, 49]. BAYRAM et al. [50] demonstrated that $\mathrm{O}_{3}$ and $\mathrm{NO}_{2}$ modulate the airway inflammation of diseases, such as bronchial asthma, by increasing the 
release of inflammatory mediators from bronchial epithelial cells, and that the cells of asthmatic subjects may be more susceptible to the adverse effects of these pollutants. It has also been observed that $\mathrm{O}_{3}$ exposure has a priming effect on allergen-induced responses as well as an intrinsic inflammatory effect in the airways of allergic asthmatics [51-54]. Indeed, $\mathrm{O}_{3}$ produces an immediate, dose-dependent increase in intracellular reactive oxygen species and in epithelial cell permeability, which could facilitate entry of inhaled allergens and toxins causing an increase in the release of inflammatory cells and their products (interleukin (IL)-1, -6, -8, tumour necrosis factor, etc.). Moreover, in an animal study mucociliary clearance times decreased as $\mathrm{O}_{3}$ increased [55].

Since inhalation of $\mathrm{O}_{3}$ by healthy subjects increases airway responsiveness and airway inflammation, asthmatic subjects were expected to be more sensitive to the acute effects of $\mathrm{O}_{3}$ [56]. Neurologically mediated inhibition of inspiratory effort involving C-fibres rather than bronchoconstriction has been proposed as the primary mechanism for $\mathrm{O}_{3}$-induced decrements in forced expiratory volume in one second (FEV1) $[47,57,58]$. In other words, stimulation of bronchial C-fibres by arachidonic acid products, such as prostaglandin $E_{2}$, may account for changes in lung function due to $\mathrm{O}_{3}$ [57]. Other pharmacological studies suggest mechanisms by which $\mathrm{O}_{3}$ acts by altering lung function. Atropine inhibits $\mathrm{O}_{3}$-induced decreases in airway resistance, suggesting a cholinergic action for this mechanism [59]. $\mathrm{O}_{3}$ also increases sensitivity to inhaled methacholine [60,61].

A study involving a high concentration of $\mathrm{O}_{3}(0.4$ parts per million (ppm)) and relatively heavy exercise [62] and another involving prolonged exposure $(7.6 \mathrm{~h})$ to a lower $\mathrm{O}_{3}$ concentration $(0.16 \mathrm{ppm})$ [63] showed enhanced responses in asthmatic subjects compared with healthy controls. Epidemiological studies have provided evidence that high ambient $\mathrm{O}_{3}$ concentrations are associated with an increased rate of asthma attacks [44, 47]. Other studies have documented increased hospital admissions or emergency department visits for respiratory disease, including asthma, after days in which there have been high $\mathrm{O}_{3}$ concentrations $[45,47]$.

Several studies suggest that $\mathrm{O}_{3}$ increases asthma morbidity by enhancing airway inflammation. $\mathrm{O}_{3}$ significantly increases levels of inflammatory mediators, such as IL-6, IL-8, granulocyte-macrophage colonystimulating factor (GM-CSF) and fibronectin, in bronchoalveolar lavage fluid (BALF) [64, 65]. Moreover, BASHA et al. [66] and SCANNEL et al. [67] found increased neutrophils, cytokine levels, and evidence of epithelial permeability in BALF $18 \mathrm{~h}$ after short-term $\mathrm{O}_{3}$ exposure, in subjects with mild asthma versus healthy subjects. In addition to increased neutrophils, PEDEN et al. [68] also found increased eosinophils in BALF $18 \mathrm{~h}$ after $\mathrm{O}_{3}$ exposure. The higher post- $\mathrm{O}_{3}$ cytokine levels, in asthmatic subjects, are consistent with the possibility that pre-existing airway inflammation in these subjects primes the inflammatory response to $\mathrm{O}_{3}$. Because $\mathrm{O}_{3}$-induced airway inflammation may last several days and $\mathrm{O}_{3}$-related asthma exacerbations often occur several days after exposure, it seems feasible that $\mathrm{O}_{3}$-induced enhancement of preexisting airway inflammation enhances susceptibility to asthma exacerbations.

$\mathrm{O}_{3}$ decreases exercise tolerance in well-trained nonasthmatic athletes [69-72]. Repeated daily, shortterm exposures of healthy subjects to $\mathrm{O}_{3}$ attenuates the acute lung function and inflammatory responses $[73,74]$. It is important to establish whether the enhanced $\mathrm{O}_{3}$-induced inflammatory responses of asthmatic persons also become attenuated with repeated daily exposures, particularly in view of the fact that exposure to high $\mathrm{O}_{3}$ concentrations may occur for several consecutive days during smog episodes. It is noteworthy that over 40-yrs-ago, STOKINGER et al. [75] found that exposure to nonlethal doses of $\mathrm{O}_{3}$ in rats enhanced their capacity to withstand subsequent exposure to higher levels, a peculiarity-defined "tolerance". Subsequent studies [76, 77] demonstrated that during 4-5 days of $\mathrm{O}_{3}$ exposure, the greatest effect on forced vital capacity and FEV1 was observed on the second day, after which there was a progressive "normalisation" of subjective and spirometric measurements [77-79]. This effect, defined "adaptation", persisted for 4-7 days after the end of exposure, and declined progressively thereafter [77, 78]. Bronchoalveolar lavage studies demonstrated that mucosal damage and inflammation continued, despite adaptation documented by clinical and spirometric evaluations [79].

It has long been speculated that $\mathrm{O}_{3}$ and other pollutants may render allergic individuals more susceptible to antigens to which they are sensitised, and animal data support such an effect [80]. Recently it has been observed that the incidence of new diagnoses of asthma are associated with heavy exercise in communities with high concentrations of $\mathrm{O}_{3}$, thus, air pollution and outdoor exercise could contribute to the development of asthma in children [81]. However, $\mathrm{O}_{3}$ can affect both the upper and lower respiratory tract and it induces more adverse effects in asthmatic individuals than in healthy subjects [38].

The outcome of two, controlled, human exposure studies supports investigations in which $\mathrm{O}_{3}$ exposure enhanced responses to inhaled antigens in animals. Thus, exposure to $\mathrm{O}_{3}$ may increase the risk of allergic sensitisation in predisposed subjects. Indeed, by lowering the threshold concentration of allergen able to induce clinical symptoms, $\mathrm{O}_{3}$ can enhance the airway responsiveness of sensitised subjects. Molfino et al. [51] reported that a $1-\mathrm{h}$ exposure to $0.12 \mathrm{ppm} \mathrm{O}_{3}$ while at rest caused a two-fold reduction in the provocation concentration of inhaled antigen required to cause early bronchoconstriction in specifically sensitised asthmatic subjects. In fact, the mean provocation dose of ragweed necessary to reduce FEV1 by $20 \%$ in specifically sensitised asthmatic subjects was significantly reduced to approximately one-half the dose of allergen when the patients were pre-exposed to $0.12 \mathrm{ppm} \mathrm{O}_{3}$ for $1 \mathrm{~h}$ versus pre-exposure to air. JORRES et al. [53], using a higher effective dose $(0.25 \mathrm{ppm}$ inhaled through a mouthpiece with intermittent exercise) and a longer duration of exposure ( $3 \mathrm{~h}$ ), found that 23 of 24 mild asthmatic subjects required 
a lower provocation dose of allergen to cause a $20 \%$ decrease in FEV1 (PD20) after $\mathrm{O}_{3}$ exposure.

BALl et al. [82] used the same protocol as Molfino et al. [51] but they avoided a limitation of the earlier study, i.e. the nonrandom ordering of exposures (filtered air before $\mathrm{O}_{3}$ in six of seven subjects) that could have produced an allergen "priming" effect on the later $\mathrm{O}_{3}$ exposures. BALL et al. [82] were unable to replicate the results of the study by Molfino et al. [51]. They found that pre-exposure to $\mathrm{O}_{3}$ versus preexposure to air did not significantly decrease the dose of allergen required to reduce FEV1 by $15 \%$. The discrepancy between the two studies was probably due to methodological differences in sample selection and to repeated exposure to the allergen used for the challenge in the study by BALL et al. [82].

In a study using $0.2 \mathrm{ppm} \mathrm{O}_{3}$ for $1 \mathrm{~h}$ with moderate exercise, CHEN et al. [83] were also unable to demonstrate a significant $\mathrm{O}_{3}$ enhancement of the early bronchoconstrictor response to allergen for their group of mild asthmatic subjects as a whole. However, the allergen concentration required to cause a $15 \%$ decrease in FEV1 was lower after $\mathrm{O}_{3}$ than after air in nine of 14 subjects. The controlled human exposure data on the effect of $\mathrm{O}_{3}$ on the early bronchoconstrictor response to inhaled allergen may be less contradictory than they appear. Peden et al. [52] have reported enhanced nasal inflammatory responses to local allergen challenge after $\mathrm{O}_{3}$ exposure in subjects with allergic rhinitis. The question of whether $\mathrm{O}_{3}$ enhances the late inflammatory response to allergen merits further investigation.

Devalia et al. [38] investigated the effect of previous exposure to $\mathrm{O}_{3}$ and $\mathrm{NO}_{2}$ on subsequent allergeninduced changes in the nasal mucosa of patients with seasonal allergic rhinitis or perennial allergic asthma. They found that exposure to these pollutants significantly increased the allergen-induced release of eosinophil cationic protein in nasal lavage. These results suggest that exposure to $\mathrm{O}_{3}$ and $\mathrm{NO}_{2}$ may "prime" the eosinophils to subsequent activation by inhaled allergen in atopic patients. Taken together, the results of the studies described above are consistent with a dose-dependent effect and they indicate that the concentration of $\mathrm{O}_{3}$ and length of exposure is critical, with a possible threshold in the region of $0.1-0.2 \mathrm{ppm}$.

\section{Nitrogen dioxide}

$\mathrm{NO}_{2}$, a precursor of photochemical smog, is found in outdoor air in urban and industrial regions and, in conjunction with sunlight and hydrocarbons, results in the production of $\mathrm{O}_{3}$. Automobile exhaust is the most significant source of outdoor $\mathrm{NO}_{2}$, although power plants and other sources that burn fossil fuels also release $\mathrm{NO}_{2}$ into the environment. Indoors, the most significant exposure to $\mathrm{NO}_{2}$ occurs in conjunction with the use of gas cooking stoves and kerosene space heaters. Most ambient $\mathrm{NO}_{2}$ is generated by the burning of fossil-derived fuels. Like $\mathrm{O}_{3}, \mathrm{NO}_{2}$ is an oxidant pollutant, although it is less chemically reactive and, thus, probably less potent. Outdoor levels of $\mathrm{NO}_{2}$ are not usually associated with notable changes in bronchial function in asthmatic patients. Controlled exposure studies of subjects with asthma have produced inconsistent results regarding the ability of $\mathrm{NO}_{2}$ to enhance nonspecific airway responsiveness, with some evidence of a subgroup with increased sensitivity [84-88]. Limited data from epidemiological studies suggest that exposure to high levels of $\mathrm{NO}_{2}$ may be associated with acute decrements in lung function in subjects with asthma [89, 90]. Two, controlled, human exposure studies, one with $\mathrm{NO}_{2}$ alone and the other with a combination of $\mathrm{NO}_{2}$ and $\mathrm{SO}_{2}$, used pollutant versus sham pre-exposure followed by allergen challenge to investigate whether allergen-induced bronchoconstriction would be enhanced. All eight asthmatic subjects studied by TUNNICLIFFE et al. [91] had a greater allergen-induced early bronchoconstrictor response after exposure to $0.4 \mathrm{ppm} \mathrm{NO}_{2}$ for $1 \mathrm{~h}$, while at rest, than after sham exposure. Seven of eight asthmatic subjects in a study by Devalia et al. [38] had a lower PD20 after exposure to $0.4 \mathrm{ppm} \mathrm{NO}_{2}$ or to $0.2 \mathrm{ppm} \mathrm{SO}_{2}$, or to the combination of both pollutants for $6 \mathrm{~h}$ than after sham exposure. However, only the combined exposure caused a significant decrease in PD20 compared with the sham control. Neither study looked at the effects of pollutants on the late inflammatory response.

\section{Sulphur dioxide}

$\mathrm{SO}_{2}$ is generated primarily from the burning of sulphur-containing fossil fuel and is released into the atmosphere primarily as a result of industrial combustion of high sulphur-containing coal and oil. $\mathrm{SO}_{2}$ has clearly been shown to induce acute bronchoconstriction in asthmatic subjects at concentrations well below those required to induce this response in healthy subjects [92, 93]. In contrast to $\mathrm{O}_{3}$, the bronchoconstrictor effect of inhaled $\mathrm{SO}_{2}$ in individuals with asthma occurs after extremely brief periods of exposure, especially with oral breathing and high ventilatory rates, as in exercise. While the data on responses of subjects with asthma to $\mathrm{NO}_{2}$ exposure are inconsistent, there is no question that brief (i.e. $<1 \mathrm{~h}$ ) exposures to low concentrations of $\mathrm{SO}_{2}$ can induce bronchoconstriction in such subjects $[94,95]$. Unlike pollutants such as $\mathrm{NO}_{2}$ and $\mathrm{O}_{3}, \mathrm{SO}_{2}$ has a rapid effect on the lung function of asthmatic subjects, and significant responses are observed within $2 \mathrm{~min}$; maximal response is seen within 5-10 minutes. There can also be spontaneous recovery $(30 \mathrm{~min}$ after challenge) and a refractory period of up to $4 \mathrm{~h}$, whereas repeated exposure to low levels of $\mathrm{SO}_{2}$ results in tolerance to subsequent exposure. Pharmacological studies seem to suggest a cholinergically-mediated neural mechanism. However, the mechanisms by which $\mathrm{SO}_{2}$ can induce asthma have yet to be completely clarified.

$\mathrm{SO}_{2}$ exposure augments responses to other environmental agents that exacerbate bronchospasm. In this context, exposure of guinea pigs to as little as $0.1 \mathrm{ppm} \mathrm{SO}_{2}$ enhanced allergic sensitisation to inhaled ovalbumin, as measured by the development 
of bronchoconstriction by specific inhalation challenge testing, and increased concentrations of specific antibodies in both BALF and serum [96].

\section{Particulate matter}

Airborne PM, which is a major component of urban air pollution, is a mixture of solid and liquid particles of different origin, size and composition, among which pollen grains and other vegetable particles carrying allergens and mould spores are included. Inhalable PM that can reach the lower airways is measured as PM10 and PM2.5 (particles with an aerodynamic diameter $<2.5 \mu \mathrm{m}$ ) [97-99]. Human lung parenchyma retains PM2.5, while particles $>5 \mu \mathrm{m}$ and $<10 \mu \mathrm{m}$ only reach the proximal airways, where they are eliminated by mucociliary clearance if the airway mucosa is intact [97-99]. PM is the most serious air pollution problem in many cities and towns and it appears to be the component of air pollution associated most consistently with adverse health effects. Particulate air pollution is significantly associated with enhanced mortality from respiratory and cardiovascular diseases, exacerbation of allergies, asthma, chronic bronchitis, respiratory tract infection and hospital admissions in many geographical areas $[25,26,100]$. Moreover, the World Health Organisation (WHO) estimates that inhalation of PM is responsible for 500,000 excess deaths each year worldwide [5]. Adverse health events have also been observed in a range of air concentrations considered safe according to WHO guidelines.

SEATON et al.. [101] hypothesised that fine PM found in urban areas is able to induce alveolar inflammation by penetrating deep into airways, which is responsible for variation in blood coagulability and release of mediators that induce acute episodes of respiratory and cardiovascular diseases. To explain the acute respiratory effects associated with inhalable PM the same authors [101] suggested that transition metals in the particles damage the airways, thereby, generating free radicals. In particular, iron, which generates hydroxyl radicals, seems to be responsible for the adverse respiratory effects [102-103]. Other transition metals (chromium, cobalt, copper, manganese, nickel, titanium, vanadium and zinc) derived from various urban or combustion source samples were also correlated to radical activation and lung injury in animal experiments [103-107].

Diesel exhaust particulate. Diesel exhaust particulate (DEP) accounts for most of the airborne PM (up to $90 \%$ ) in the atmosphere of the world's largest cities [108-115]. It is characterised by a carbonaceous core in which 18,000 different high molecular weight organic compounds are adsorbed. DEP presents a large number of particles, $\sim 100$ times more particles per mile than petrol engines of equivalent power. Although diesel engines emit far less carbon dioxide $\left(\mathrm{CO}_{2}\right)$ than petrol engines, they emit $>10$ times more $\mathrm{NO}_{2}$, aldehydes and respirable PM than unleaded petrol engines and $>100$ times more than engines fitted with catalytic converters [108]. DEPs exert their effects by way of specific activities of chemical agents, i.e. polyaromatic hydrocarbons (PAHs). The particles are deposited on the mucosa of the airways, and by virtue of their hydrophobic nature, the PAHs allow them to diffuse easily through cell membranes and bind to a cytosolic receptor complex. Through the subsequent nuclear action, PAHs can modify the growth and the differentiation programmes of cells [114].

Acute exposure to diesel exhaust causes irritation of the nose and eyes, lung function changes, respiratory changes, headache, fatigue and nausea, while chronic exposure is associated with cough, sputum production and lung function decrements [108, 109]. Experimental studies have shown that DEP causes respiratory symptoms and is able to modify the immune response in predisposed animals and humans [111-115]. In fact, DEP seems to exert an adjuvant immunological effect on $\operatorname{IgE}$ synthesis in atopic subjects, thereby, influencing sensitisation to airborne allergens. Nearly a decade ago, RUDELL et al. [116] showed that healthy volunteers exposed to DEP had a greater number of alveolar macrophages, neutrophils and T-lymphocytes in BALF than did controls. In the wake of these and other observations $[115,116]$, recent studies confirmed the effects favouring airway inflammation and demonstrated an atopy-enhancing effect of diesel exhaust [113, 114].

DIAZ-SANCHEZ and co-workers [113, 114] studied the effect of DEP on antigen in ragweed-sensitive subjects challenged (nasal provocation test) with DEP, Amb al (the major ragweed allergen) and a combination of DEP and Amb a1. Provocation with ragweed led to an increase in both total and ragweed-specific IgE in nasal lavage fluid measured $18 \mathrm{~h}, 4$ days and 8 days postchallenge. The DEP challenge increased the concentration of ragweed-specific IgE 16-fold versus concentrations observed after challenge with ragweed alone. The same group observed that combined DEP and ragweed allergen challenge markedly enhances human in vivo nasal ragweed-specific $\operatorname{IgE}$ and skews cytokine production to a T-helper cell type-2 (Th2) pattern [114]. All these results indicate that DEP plays a role in the enhanced allergic inflammatory response [114-116].

As to the underlying DEP-related allergic respiratory disease, DEP can adsorb aeroallergens released by pollen grains and can prolong the retention of the allergen so as to provide for an enhanced IgEmediated response [117]. DEPs exert their effect by way of components such as the hydrophobic PAHs. The DEP is deposited on the airway mucous membranes (epithelial cells and macrophages are the first cells to come into contact with inhaled PM) and the PAHs allow them to diffuse easily through cell membranes and bind to a cytosolic receptor complex. Through the subsequent nuclear action, PAHs can modify the growth and the differentiation programmes of cells [114-116].

Human epithelial cells and macrophages phagocyte the DEP leading to the production of the inflammatory cytokines IL-6, IL-8 and GM-CSF [109, 115]. IL-8, which is increased in lung and nasal washes of asthmatic and/or rhinitic subjects, activates chemotaxis of lymphocytes, neutrophils and eosinophils, and 
causes histamine release, plasma leakage, smooth muscle contraction of airways and increased airway hyperresponsiveness.

The data on DEP are of particular interest in view of the increasing percentage of new cars with diesel engines in industrialised countries. In fact, during the early 1990s, concern about the greenhouse gases produced by petrol engines caused various industrialised countries to reduce the duty on diesel fuel and increased the duty on gasoline with a view to decreasing greenhouse emissions. In Europe, for example, $50 \%$ of all new cars are diesel powered thanks to their lower maintenance costs. Diesel-powered cars are usually promoted as being environmentally friendly because they produce up to $25 \%$ less $\mathrm{CO}_{2}$, which is a major contributor to global warming. However, since diesel engines are a major source of inhalable PM, perhaps the policy of encouraging their use should be reconsidered.

\section{Plant-derived allergens}

Pollen in urban areas. Respiratory allergy induced by antigens released by pollen grains is very common [32, $118]$. For instance, between $8-35 \%$ of young adults in countries of the European Community have IgE serum antibodies to grass pollen allergens [119]. The cost of pollen allergy in terms of impaired work fitness, sick leave, consulting physicians and drugs, is very high.

Subjects living in urban areas tend to be more affected by plant-derived respiratory disorders than those living in rural areas. IsHIzAKI et al. [120] observed that respiratory allergy was more prevalent in subjects living near busy roads than in subjects living in areas with higher atmospheric concentrations of pollen allergens but with less traffic. These results should be interpreted with caution because they can be affected by several factors that were not examined. However, various studies suggest that there is an interaction between air pollutants and allergens that exacerbates the development of atopy and the respiratory symptoms of allergic disease (table 1). In a time-series study BRUNEKREEF et al. [29] found a strong association between the day-to-day variation in pollen concentrations and deaths due to cardiovascular disease, chronic obstructive pulmonary disease, and pneumonia.

To prevent pollen allergy, an ideal but hardly feasible approach, is to minimise the risk of contact with these agents by moving to a nonrisk area. A much easier alternative, is to reduce inhalation of pollen allergens by remaining at home with the windows closed [121] (figs 1 and 2).

Table 1.- How pollutants may increase acute responses to allergen

Increased epithelial permeability

Airway inflammation causing "priming" of allergen-induced responses (i.e. enhanced recruitment and activation of inflammatory cells)

Increased oxidative stress in the airways Increased neuropeptide release

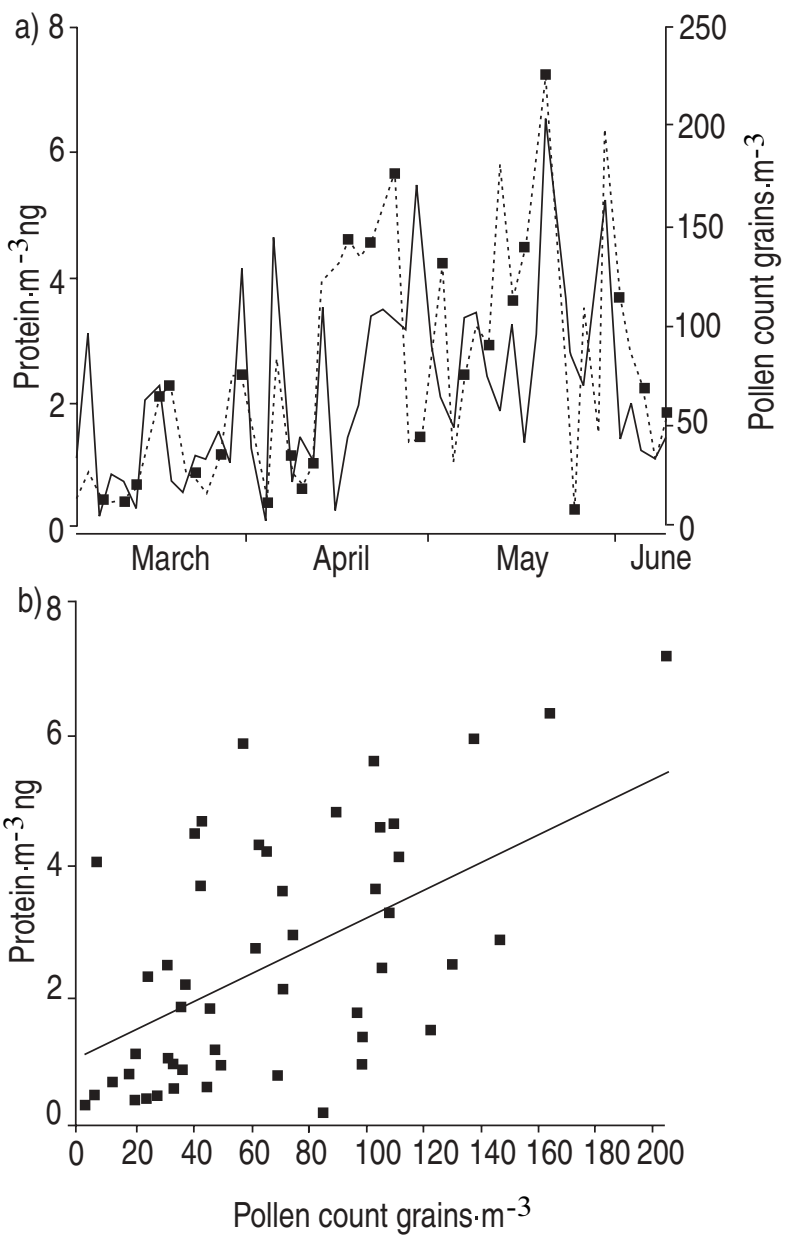

Fig. 1.-a) Comparison between Parietaria pollen count (grains $\cdot \mathrm{m}^{-3}$ of air as daily mean value using a Hirst-like volumetric device; solid line) and Parietaria aeroallergen activity outdoor (proteins $\cdot \mathrm{m}^{-3} \mathrm{ng}$ of air during $4 \mathrm{~h}$ of daily sampling with a highvolume air sampler on the days indicated; dotted line) in the year 2000. b) Linear regression between pollen count (grains $\cdot \mathrm{m}^{-3}$ ) and outdoor airborne allergenic activity (protein $\cdot \mathrm{m}^{-3} \mathrm{ng}$ ).

Airborne paucimicronic allergen-carrying particles. Pollen grains are the primary carriers of pollen allergens, which explains why the symptoms typical of hay fever are located in the eyes, nose and nasopharynx. Differently, allergic asthma in pollen-sensitive patients is an enigma because intact pollen grains, measuring $>10 \mu \mathrm{m}$ in diameter, are too large to enter the lower airways $[32,122,123]$. Moreover, in many instances peak asthma symptom scores differ temporally from peak pollen counts, and early morning symptoms sometimes precede later peaks in the daily pollen cycle.

The aetiology of pollen asthma and the discordance between pollen count and bronchial symptoms was partially explained with the identification of pollen allergens in microaerosol suspensions smaller than pollen grains [34, 124-128], which could be present in the atmosphere before the start and after the end of the season, so prolonging the respiratory symptoms of sensitised patients. By virtue of their small size, these paucimicronic particles can reach the peripheral airways with inhaled air, so inducing asthma in sensitised subjects (table 2). Thus, parts of an 

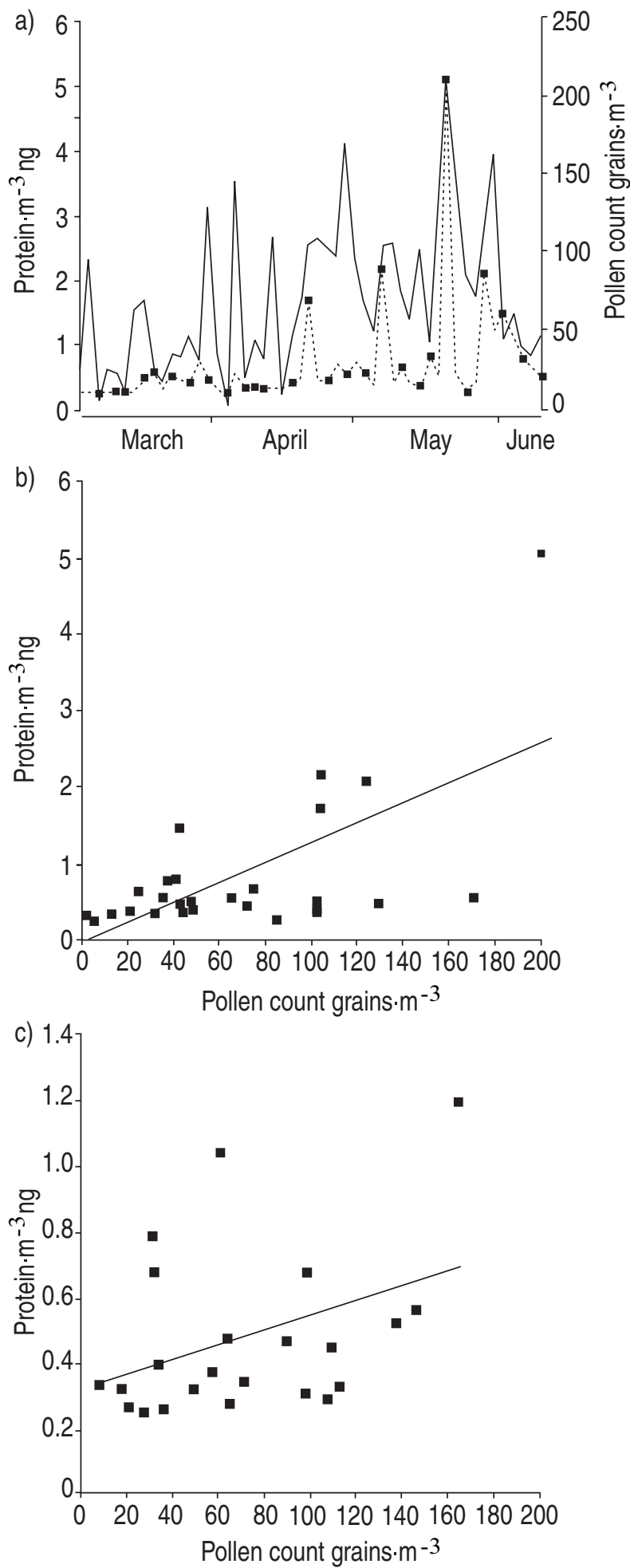

Fig. 2. - a) Comparison between Parietaria pollen count (grains $\cdot \mathrm{m}^{-3}$ of air as daily mean value; solid line) and Parietaria aeroallergen activity indoor (protein $\cdot \mathrm{m}^{-3} \mathrm{ng}$ of air during $4 \mathrm{~h}$ daily of sampling with highvolume air sampler on the days indicated; dotted line) in the year 2000. b) Linear regression between pollen count (grains $\cdot \mathrm{m}^{-3}$ ) and indoor airborne allergenic activity with the balcony open (protein $\cdot \mathrm{m}^{-3} \mathrm{ng}$ ). c) Linear regression between pollen count (grains $\cdot \mathrm{m}^{-3}$ ) and indoor airborne allergenic activity with the balcony closed (protein $\cdot \mathrm{m}^{-3} \mathrm{ng}$ ). With balcony closed, the indoor allergenic activity during the flowering season of Parietaria is reduced by approximately one-third with respect to outdoor concentrations. There was very little difference between indoor and outdoor concentrations when windows were open.
Table 2. - Airborne small allergen-carrying particles

Pollen fragments

Starch granules (released into the atmosphere under wet conditions and responsible for bronchial asthma outbreaks, thunderstorm associated)

Nonpollen plant parts (from inflorescences, leaves or Ubish bodies)

Nonplant particulate matter (allergens transferred through physical contact or by leaching from the surface of the pollen grain to other airborne small particles)

organism (in this case of vegetable nature) other than pollen grains or spores contain significant allergen concentrations that are readily disseminated via an airborne route. These allergenic paucimicronic particles act only as carriers for the protein agent with antigenic property that causes symptoms.

Allergens have been detected in the leaves and stems of allergenic plants [34]. They may result from elution of allergens from pollen grains with their later dispersion in microdroplets. Moreover, pollen grain allergens could be transferred, by physical contact or by elution, to other small particles present in the atmosphere, for instance DEP, which can penetrate deep into the airways [117]. Consequently, besides enhancing airway ragweed-specific IgE and skewing cytokine production to a T-helper cell type-2 pattern in subjects at risk of developing atopy [114], DEP could cause asthma by trafficking allergens into the airways.

Thunderstorm-associated asthma induced by allergenic airborne paucimicronic particles derived from grass pollens. Suphioglu et al. [129] and KNox [35] found that under wet conditions or during thunderstorms, pollen grains may, after rupture by osmotic shock, release part of their content, including respirable, allergen carrying starch granules $(0.5-2.5 \mu \mathrm{m})$ into the atmosphere. "Thunderstorm-associated asthma" was recognised > 15 -yrs-ago in Britain by PACKE and AYRES $[130,131]$, who described an association between a thunderstorm and an asthma outbreak with 26 asthmatic subjects treated in the Birmingham Hospital, $\mathrm{UK}$, in $36 \mathrm{~h}$ compared with $2-3$ cases in the same time in the days preceding the thunderstorm. Other asthma outbreaks during thunderstorms were described in Melbourne, Australia [132]. This phenomenon was also followed by a rapid increase in hospital or general practitioner visits for asthma. No unusual levels of air pollution were noted at the time of these epidemics but there was a strong association with rye grass pollen [35, 133-136]. Rye grass pollens, after rupture by osmotic shock during thunderstorms, release large amounts of paucimicronic allergenic particles, i.e. cytoplasmatic starch granules containing grass allergens such as Lol p 9 and coated with Lol p 1 [35]. Because of their very small size, starch granules can penetrate the lower airways and induce the appearance of bronchial allergic symptoms. Other thunderstorm-associated asthma outbreaks occurred in London, UK, on the night between June 24-25 1944 [133-135] and in Wagga Wagga, Australia on October 30, 1997 [136]. The asthma outbreak of London was the largest episode; 
there were $\sim 100$ emergency visits of several hospitals of London and southwest England. Interestingly, in the London outbreak several patients examined, who were not known to be asthmatics or were affected only by seasonal rhinitis, experienced an asthma attack [36, 37, 135]. This explains why grass induces mainly allergic rhinitis in sensitised atopic subjects. In fact, being $>30 \mu \mathrm{m}$, intact grass pollen grains can only reach the lower airways after rupture.

Allergenic airborne Ubish bodies. Another minute vehicle for allergens are Ubish bodies [122, 137-140]. These spheroidal structures, which develop with the pollen exine, are found in the anthers of many higher plants. Their function is unknown. They generally occur in large numbers, are usually only a few micrometres in diameter and can contain allergens $[138,141,142]$. The walls of the coating of Ubish bodies consist of sporopollenin similar to pollen exine and are usually thick in proportion to the overall size of the Ubish body. The overall shape and in some instances the surface architecture of Ubish bodies is similar to the pollen grain with which it is associated. Consequently, the Ubish bodies could be a means of organising structures similar to pollen, but less complex, and in smaller cytoplasmic units. With the final autolysis of the tapetal cells, the Ubish bodies tend to lie irregularly upon the remnants of the tapetum amongst the maturing pollen grains. Ubish bodies may be involved in the dispersal of pollen and their size is optimal for penetration into lower airways.

Besides providing an explanation for bronchial asthma symptoms in pollinosis patients, a practical offshoot of these studies is that the traditional "pollen count" may be misleading as an index of outdoor allergen exposure in particular situations. In fact, the pollen count technique consists of examination of pollen grains collected in volumetric "pollen traps" under the microscope and the definition of their concentration per cubic metre of air, whereas immunochemical methods are required to identify the allergens carried by airborne microparticulate matter such as starch granules and Ubish bodies [143, 144]. It would be interesting to quantify atmospheric variations in these biological aerosols and in their allergenic activity in an attempt to establish correlations with clinical symptoms and to estimate the different risks for asthma and hay fever patients sensitive to pollen allergens [145].

It is also important to note that starting with pollen, the interest in smaller airborne allergenic units now embraces a variety of agents (e.g. house dust, arthropod emanations, and animal allergens) of undefined or variable particle size [144, 145]. The advent of high speed impingers, which are very efficient in collecting small aerosols on filters, has given impetus to the study of a variety of environmental agents, and antigenic activity has been identified on both micronic and submicronic fractions.

Other plant-derived antigens responsible for epidemic asthma in urban areas. Soybean dust was responsible for outbreaks of severe asthma that were first attributed to urban air pollution. Examples are asthma epidemics in cities with large industrial port facilities. From 1981-1987, 26 outbreaks of asthma with 11 deaths occurred in Barcelona, Spain, without any apparent relation to air pollution [146]. The aetiological agent was subsequently found to be soybean dust released into the air during unloading of cargo into a harbour silo that was not equipped with a dustcontrol device. ANTò et al. [146] demonstrated that $\sim 74 \%$ of epidemic cases had specific IgE antibodies versus a commercial soybean antigen in comparison with $4.6 \%$ of controls. In addition, using the assays of urban aerosols collected with high volume samplers and the radioallergosorbent test (RAST) inhibition technique, they demonstrated highly significant differences in the atmospheric content of soybean antigens between days marked by the asthma epidemic and days free of an excess of asthma cases [147]. The strong association between airborne soybean dust and asthma outbreaks was reinforced by the results of studies showing high airborne concentrations on epidemic days and low values on nonepidemic days [146]. All these studies showed that asthma outbreaks were a "point-source" epidemic. Protective measures, i.e. cargo unloading after filters were fitted to the grain elevators, dramatically reduced airborne allergen levels of soybean dust and visits for asthma to the emergency room [148]. The IgE serum levels in exposed subjects also decreased progressively.

Other outbreaks of asthma caused by soybean dust pollution have been documented in the Spanish cities of Tarragona and Cartagena [149, 150]. In Naples, Italy, $>100$ patients were admitted to hospital for asthma in a single day in December 1993 [151]. This asthma outbreak coincided with the unloading of a cargo of soybean. Interestingly, neither in the Barcelona nor in the Naples outbreaks were there cases of severe asthma attacks in children.

Recently, the asthma epidemic that occurred in New Orleans, LO, USA, in 1969 [152, 153] was re-examined [154]. It was found that the number of asthma attacks was higher on days when ships carrying soybean were anchored in the harbour. Attacks were also higher in concomitance with air stagnation and with winds carrying particles from two grain elevators. No association was observed between asthma attacks and the presence of ships carrying wheat or corn [154].

\section{Air pollution, climate changes and pollen-related respiratory allergy}

The role of climatic factors (e.g. barometric pressure, temperature and humidity) in triggering and/or exacerbating respiratory allergic symptoms in predisposed subjects is still poorly understood [14] and asthma attacks have been linked with both low [36] and high [155] atmospheric pressure. In other words, studies are required to clarify the role of weather in morbidity and mortality for respiratory allergy [156, 157].

There is still much to learn about the effects of other climatic factors that seem to be important to asthma, e.g. wind speed and passage of cold fronts. It is well known that inhalation of cold air reduces lung 
function in asthmatics, thus, favouring bronchoconstriction. Moreover, exercise in polluted areas results in greater deposition of air pollutants, including allergen-carrying allergens, in the lower airways. In fact, exercise increases oral breathing, total ventilation and inertial impaction of inhaled particles in the airways. There is also the thorny question as to how increasing levels of greenhouse gases and concomitant climate changes will influence the frequency and severity of pollen-induced respiratory allergy [33, 158]. A variety of direct and indirect evidence suggests that climate changes may affect pollen release and consequently pollen-related asthma $[158,159]$. Climate variations are likely to influence vegetation with consequent changes in growth, reproductive cycle, etc., and in the production of allergenic pollen (seasonal period and intensity) with a greater proliferation of weed species. Climate changes vary from region to region; some areas will be subject to increases in ultraviolet radiation and/or rainfall frequency and other areas to reductions.

In Italy, in the 20 yrs from 1981-2000, the average mean temperature has increased by $\sim 0.6^{\circ} \mathrm{C}$. This warming is accompanied by an average reduction of $15 \%$ in rainfall, and the rain is concentrated in a shorter period causing more violent rainstorms [160]. How are allergenic plants responding to these changes? The increased temperature in winter and spring has brought about early pollination, and the increased summer temperature has resulted in a prolonging of the pollination of herbaceous, allergenic plants such as Urticaceae. In warmer years, allergy symptoms started $\sim 1-2$ weeks earlier. Pollen seasons, and therefore seasonal allergic symptoms, tend to be longer in warmer years. The prolonging of autumn could prolong the presence of fungal spores in the atmosphere. Because of the "urban climate effect" (heating caused by high building density and soil sealing), pollination can occur 2-4 days earlier in urban than in rural areas.

Vegetation reacts with air pollution over a wide range of pollutant concentrations and environmental conditions. Many factors influence the interaction, including type of air pollutant, plant species, nutrient balance, soil conditions and climatic factors. At low levels of exposure for a given species and pollutant, no significant effect is observed. However, as the exposure level increases, there may be biochemical alterations of the plants [158] (table 3). Plants can absorb pollutants through the leaves or through the root system. In the latter case, deposition of air pollutants on soils can alter the nutrient content of soil in the proximity of the plant, thus, leading to indirect or secondary effects of air pollutants on vegetation. Metabolic variations affect the plant's structural integrity and there are probably changes in the pollen proteins, including those acting as allergens.

Air pollution can influence the plant allergenic content, and by affecting plant growth, it can affect both the amount of pollen produced and the amount of allergenic proteins contained in pollen grains. The pollen of plants stressed by air pollution express enhanced levels of allergenic proteins [158]. Pollen grains collected from roadsides with heavy traffic and from other areas with high levels of air pollution, are covered with large numbers of microparticulates (usually $<5 \mu \mathrm{m}$ in diameter) and it appears that interaction between air pollution components and pollen allergens alters the antigenicity of pollen allergens [161].

In this context, Naples, Italy, provides a tool with which to study the interrelationship between $\mathrm{O}_{3}$ and pollen-derived allergens due to its high production of photochemical smog and year-long sunny days. The climate also favours the pollination of Parietaria, which grows in abundance throughout the city [14, 33, 143, 162]; $\sim 30 \%$ of Neapolitans are allergic to this plant and $>50 \%$ of these Parietaria pollen-allergic subjects experience bronchial asthma and its equivalent, with high levels of bronchial hyperresponsiveness. The authors have observed that cases of pollen-induced respiratory symptoms tend to increase when there is a parallel increase in the atmosphere of $\mathrm{O}_{3}, \mathrm{PM} 10$ and Parietaria pollen. This parallel increase usually starts in February and reaches its peak in June or July, after which the production and release of Parietaria pollen usually decreases, whereas $\mathrm{O}_{3}$ and $\mathrm{PM}$ remain high into the autumn. In addition, Parietaria pollen and $\mathrm{O}_{3}$ reach their highest levels in morning. Parietaria peaks earlier than $\mathrm{O}_{3}$ because of the time required for the photochemical reaction to develop.

In an attempt to test the hypothesis of an interaction between air pollution and pollen grains, the authors examined the effect of various polluting agents (gas from cars powered by normal and catalysed petrol, from diesel cars and from motorcycles) on the pollen of Parietaria. They placed $150 \mathrm{mg}$ of pollen in tubes each filled with different exhaust gas. After seven days the Parietaria pollen samples at $5 \%$ weight per volume were extracted overnight. The solutions were centrifuged and the

Table 3. - Rationale for the interrelationship between components of air pollution and allergens in inducing respiratory allergy

Components of air pollution can interact with pollen grains, leading to increased release of antigens characterised by modified allergenicity

Components of air pollution can interact with allergen-carrying paucimicronic particles derived from plants, which are able to reach the peripheral airways with inhaled air, inducing asthma in sensitised subjects

Components of air pollution, especially ozone, particulate matter and sulphur dioxide, have an inflammatory effect on the airways of susceptible subjects, causing increased permeability, easier penetration of pollen allergens in the mucous membranes and easier interaction with cells of the immune system. There is also evidence that predisposed subjects have increased airway reactivity induced by air pollution and increased bronchial responsiveness to inhaled pollen allergens

Components of air pollution, in particular diesel exhaust particles, have an adjuvant immunological effect on immunoglobulin E synthesis in atopic subjects 
supernatants collected and filtered. The allergenic potency was determined by the RAST inhibition test. It was found that exhaust emissions from noncatalytic cars increased the allergenic potency of Parietaria pollen as compared with exhaust emissions from catalytic cars [14].

\section{Conclusion}

The prevalence of allergic respiratory diseases such as bronchial asthma appears to have increased, especially in industrialised countries. A change in the genetic predisposition is an unlikely cause of the increase in allergic diseases because genetic changes in a population require thousands of years. Consequently, the increase may be explained by changes in environmental factors, e.g. food, drugs, infections, emotional components, and components of indoor and outdoor air pollution. Over the past two decades there has been increasing interest in studies of air pollution and its effects on human health. Although the role played by outdoor pollutants in allergic sensitisation of the airways has yet to be clarified, a body of evidence suggests that urbanisation, with its high levels of vehicle emissions, and a Westernised lifestyle are linked to the rising frequency of respiratory allergic diseases seen in most industrialised countries, and there is considerable evidence that asthmatic persons are at increased risk of developing exacerbations with exposure to $\mathrm{O}_{3}, \mathrm{NO}_{2}, \mathrm{SO}_{2}$ and inhalable PM pollution. However, it is not easy to evaluate the impact of the air pollution components on the timing of asthma exacerbations and on the prevalence of asthma in general.

Pollinosis is frequently used to study the interrelationship between air pollution and respiratory allergy. Climatic factors (wind speed, temperature, humidity, etc.) can affect both components (biological and chemical) of this interaction. By attaching to the surface of pollen grains and of plant-derived paucimicronic particles, pollutants can modify the morphology of these antigen-carrying agents and alter their allergenic potential. In addition, by inducing airway inflammation, which increases airway permeability, pollutants overcome the mucosal barrier and so "prime" allergen-induced responses. Since concentrations of airborne allergens and air pollutants are frequently increased contemporaneously, an enhanced Immunoglobulin E-mediated response to aeroallergens and enhanced airway inflammation could account for the increasing frequency of allergic respiratory allergy. It is important to stimulate governments and international organisations to set new health-based air quality standards for breathable air.

\section{References}

1. Plinius the Younger. Letter to Tacitus (letter VI.16) 105 AD. Rome, Italy.

2. European Community Respiratory Health Survey. Variations in the prevalence of respiratory symptoms, self-reported asthma attacks and the use of asthma medications in the European Community Respiratory Health Survey (ECRHS). Eur Respir J 1996; 9: 687695.

3. Woolcock AJ, Peat JK. Evidence for the increase in asthma worldwide. In: The Rising Trend in Asthma. Ciba Foundation Symposium. Chicester, John Wiley \& Sons, 1997; pp. 122-139.

4. The International Study of Asthma and Allergy in Childhood (ISAAC) Steering Committee. Worldwide variation in prevalence of symptoms of asthma, allergic rhinoconjunctivitis and atopic eczema. Lancet 1998; 351: 1225-1232.

5. United Nations Environment Programme and World Health Organisation Report. Air pollution in the world's megacities. A report from the United Nations Environment Programme and World Health Organisation. Environment 1994; 36: 5-37.

6. American Thoracic Society. Health effects of outdoor air pollution. Part I. Am J Respir Crit Care Med 1996; 153: 3-50.

7. American Thoracic Society. Health effects of outdoor air pollution. Part II. Am J Respir Crit Care Med 1996; 153: 477-498.

8. Lebowitz MD. Epidemiological studies of the respiratory effects of air pollution. Eur Respir J 1996; 9: 1029-1054.

9. Gielen $\mathrm{MH}$, van der Zee SC, van Eijenen JH, van Steen CJ, Brunekreef B. Acute effects of summer air pollution on respiratory health of asthmatic children. Am J Respir Crit Care Med 1997; 155: 2105-2108.

10. Viegi G, Enarson DA. Human health effects of air pollution from mobile sources in Europe. Int $J$ Tuberc Lung Dis 1998; 2: 947-967.

11. Holgate S, Samet JM, Koren HS, Maynard RL. Air Pollution and Health. Academic Press, London, 1999.

12. Riedler J, Eder W, Oberfeld G, Schrener M. Austrian children living on a farm have less hay fever, asthma and allergic sensitization. Clin Exp Allergy 2000; 30: 194-200.

13. Braun-Fahrlander C, Gassner M, Grize L, et al. Prevalence of hay fever and allergic sensitization in farmers' children and their peers living in the same rural community. SCARPOL team. Swiss study on childhood allergy and respiratory symptoms with respect to air pollution. Clin Exp Allergy 1999; 29: $28-34$.

14. D'Amato G, Liccardi G, D'Amato M, Cazzola M. The role of outdoor air pollution and climatic changes on the rising trends in respiratory allergy. Respir Med 2001; 95: 606-611.

15. Wjst M, Reitneir P, Dold S, et al. Road traffic and adverse effects on respiratory health in children. BMJ 1993; 307: 596-600.

16. Edwards J, Walters S, Griffiths RK. Hospital admissions for asthma in preschool children: relationship to major roads in Birmingham, United Kingdom. Arch Environ Health 1994; 49: 223-227.

17. Osterlee A, Drijver M, Lebret E, Brunekreef B. Chronic respiratory symptoms in children and adults living along street with high traffic density. Occup Environ Med 1996; 53: 241-247.

18. Boezen HM, van der Zee SC, Postma DS, et al. Effects of ambient air pollution on upper and lower respiratory symptoms and peak expiratory flow in children. Lancet 1999; 353: 874-878.

19. Sunyer J, Saez M, Murillo C, Castellsague JMF. Air 
pollution and emergency room admission for chronic obstructive pulmonary disease: A 5-year study. Am J Epidemiol 1993; 137: 701-705.

20. Atkinson RW, Anderson HR, Strachan DP, Bland JM, Bremner SA, Ponce de Leon A. Short-term associations between outdoor air pollution and visits to accident and emergency departments in London for respiratory complaints. Eur Respir J 1999; 13: 257265.

21. Künzli N, Kaiser R, Medina S, et al. Public health impact of outdoor and traffic-related air pollution: A European assessment. Lancet 2000; 356: 795-801.

22. Dockery DW, Pope CA, Xu X, et al. An association between air pollution and mortality in six US cities. New Engl J Med 1993; 329: 1753-1759.

23. Schwartz J. The distributed lag between air pollution and daily deaths. Epidemiology 2000; 11:320 326.

24. Schencker M. Air pollution and mortality. $N$ Engl J Med 1993; 329: 1807-1808.

25. Pope A, Thun M, Namboodiri M, et al. Particulate air pollution as a predictor of mortality in a prospective study of U.S.Adults. Am J Respir Crit Care Med 1995; 151: 669-674.

26. Katsouyanni K, Touloumi G, Spix C. Short-term effects of ambient sulphur dioxide and particulate matter on mortality in 12 European cities: results from times series data from the APHEA project. BMJ 1997; 314: 1658-1663.

27. Abbey D, Nishino N, McDonnell WF, et al. Longterm inhalable particles and other air pollutants related to mortality in nonsmokers. Am J Respir Crit Care Med 1999; 159: 373-382.

28. Pope CA. Mortality and air pollution: Association persists with continued advances in research methodology. Environ Health Perspect 1999; 107: 613-614.

29. Brunekreef B, Hoek G, Fischer P, Spieksma FTHM. Relation between airborne pollen concentrations and daily cardiovascular and respiratory-disease mortality. Lancet 2000; 355: 1517-1518.

30. Rossi OVJ, Kinnula VL, Tienari J, et al. Association of severe asthma attacks with weather, pollen and air pollutants. Thorax 1993; 30: 2-8.

31. Anderson HR, Ponce de Leon A, Bland JM, Bower JS, Emberlin J, Strachan DP. Air pollution, pollens and daily admissions for asthma in London. Thorax 1998; 53: 842-848.

32. D'Amato G, Spieksma FTHM, Liccardi G, et al. Pollen-related allergy in Europe. Position paper of the European Academy of Allergology and Clinical Immunology. Allergy 1998; 53: 567-578.

33. D'Amato G. Urban air pollution and plant-derived respiratory allergy. Clin Exp Allergy 2000; 30: 628636.

34. D'Amato G, De Palma R, Verga A, Liccardi G, Lobefalo G. Antigenic activity of non pollen parts (leaves and stems) of allergenic plants. Ann Allergy 1991; 67: 421-424.

35. Knox RB. Grass pollen, thunderstorms and asthma. Clin Exp Allergy 1993; 23: 354-359.

36. Celenza A, Fothergill J, Kupek E, Shaw RJ. Thunderstorms associated asthma: A detailed analysis of environmental factors. BMJ 1996; 312: 604-607.

37. Venables KM, Allitt U, Collier CG, et al. Thunderstormrelated asthma - epidemic 24/25 June 1994. Clin Exp Allergy 1997; 27: 725-736.

38. Devalia JL, Rusznak C, Davies RJ. Allergen/irritant interaction - its role in sensitization and allergic disease. Allergy 1998; 53: 335-345.

39. Rusznak C, Devalia JL, Davies RJ. The airway response of asthmatics to inhaled allergen after exposure to pollutants. Thorax 1996; 344: 1668-1671.

40. D'Amato G, Liccardi G. Environmental injury of airways and allergic respiratory diseases. Pulm Pharmacol Ther 1998; 11: 369-374.

41. Corren J. Allergic rhinitis and asthma: How important is the link? J Allergy Clin Immunol 1997; 99: S781S786.

42. D'Amato G. The link between allergic asthma and rhinitis. Mon Arch Chest Dis 2000; 6: 471-474.

43. Whittemore AS, Korn EL. Asthma and air pollution in the Los Angeles area. Am J Public Health 1980; 70: 687-696.

44. Holguin $\mathrm{AH}$, Buffler $\mathrm{C}$, Contant $\mathrm{CF}$, et al. The effect of ozone on asthmatics in the Houston area. In: Lee $\mathrm{SD}$, ed. Evaluation of the Scientific Basis for Ozone/ Oxidants Standards. Pittsburg, Air Pollution Control Association, 1985; pp. 262-280.

45. Bates DV, Sizto R. Relationship between air pollution levels and hospital admissions in southern Ontario. Can J Public Health 1983; 74: 117-133.

46. Balmes JR. The role of ozone exposure in the epidemiology of asthma. Environ Health Perspect 1993; 101: Suppl. 4, 219-224.

47. White MC, Etzel RA, Wilcox WD, Lloyd C. Exacerbations of childhood asthma and ozone pollution in Atlanta. Environ Res 1994; 65: 56-68.

48. Thurston GD, Gwynn RC. Ozone and asthma mortality/hospital admissions in New York City. Am J Respir Crit Care Med 1997; 155: A426.

49. Peters JM, Avol E, Gauderman WJ, et al. A study of twelve Southern California communities with differing levels and types of air pollution. II. Effects on pulmonary function. Am J Respir Crit Care Med 1999; 159: 768-775.

50. Bayram H, Sapsford RJ, Abdelaziz MM, Khair OA. Effect of ozone and nitrogen dioxide on the release of proinflammatory mediators from bronchial epithelial cells on nonatopic, nonasthmatic subjects and atopic asthmatic patients in vitro. $J$ Allergy Clin Immunol 2001; 107: 287-294.

51. Molfino NA, Wright SC, Katz I, et al. Effect of low concentration of ozone on inhaled allergen responses in asthmatic subjects. Lancet 1991; 338: 199-203.

52. Peden DB, Setzer RW, Devlin RB. Ozone exposure has both a priming effect on allergen induced responses as well as an intrinsic inflammatory action in the nasal airways of perennial allergic asthmatics. Am J Respir Crit Care Med 1995; 151: 1336-1345.

53. Jorres R, Nowak D, Magnussen H. Effect of ozone exposure on allergen responsiveness in subjects with asthma or rhinitis. Am J Respir Crit Care Med 1996; 153: 56-64.

54. Kehrl HR, Peden DB, Ball B, Folinsbee LJ, Horstrom D. Increased specific airway reactivity of persons with mild allergic asthma after 76 hours of exposure to 0.16 ppm ozone. J Allergy Clin Immunol 1999; 104: $1198-1204$.

55. Schlesinger RB, Driscoll KE. Mucociliary clearance from the lungs of rabbits following single and intermittent exposures to ozone. $J$ Toxicol Environ Health 1987; 20: 125-134.

56. McDonnell WF, Horstman DH, Abdul-Salaam S, Raggio LJ, Green JA. The respiratory responses of 
subjects with allergic rhinitis to ozone exposure and their relationship to nonspecific airway reactivity. Toxicol Ind Health 1987; 3: 507-517.

57. Coleridge HM, Coleridge JCG, Ginzel KH, et al. Stimulation of "irritant" receptors and afferent C-fibres in the lungs by prostaglandins. Nature 1976; 264: 451-452.

58. Coleridge JCG, Coleridge HM, Schelegle ES, Green JF. Acute inhalation of ozone stimulates bronchial C-fibres and rapidly adapting receptors in dogs. $J$ Appl Physiol 1993; 74: 2345-2352.

59. Beckett WS, McDonnell WF, Horstman DH, et al. Role of the parasympathetic nervous system in acute lung response to ozone. J Appl Physiol 1985; 59: 18791885.

60. Holtzman MJ, Fabbri LM, O'Byrne PM, et al. Importance of airway inflammation for hyperresponsiveness induced by ozone. Am Rev Respir Dis 1983; 127: 686-690.

61. Folinsbee LJ, Horstman DH, Kehrl HR, et al. Respiratory responses to repeated prolonged exposure to 0.12 ppm ozone. Am J Respir Crit Care Med 1994; 149: 98-105.

62. Kreit JW, Gross KB, Moore TB, et al. Ozone-induced changes in pulmonary function and bronchial responsiveness in asthmatics. J Appl Physiol 1989; 66: $217-$ 222.

63. Horstman D, Ball BA, Brown J, Gerrity T, Folinsbee LJ. Comparison of asthmatic and nonasthmatic subjects performing light exercise while exposed to a low level of ozone. Toxicol Ind Health 1995; 11: 369 385.

64. Devlin RB, McDonnell WF, Mann R. Exposure of humans to ambient levels of ozone for 6.6 hours causes cellular and biochemical changes in the lung. Am J Respir Cell Mol Biol 1991; 4: 72-81.

65. Balmes JR, Aris RM, Chen LL, et al. Effects of ozone on normal and potentially sensitive human subjects. Part I: airway inflammation and responsiveness to ozone in normal and asthmatic subjects. Respir Rep Health Eff Inst 1997; 78: 1-37.

66. Basha MA, Gross KB, Gwizdala CJ, Haidar AH, Popovich J. Bronchoalveolar lavage neutrophilia in asthmatic and healthy volunteers after controlled exposure to ozone and purified air. Chest 1994; 106: $1757-1765$.

67. Scannell C, Chen LL, Aris RM, et al. Greater ozoneinduced inflammatory responses in subjects with asthma. Am J Respir Crit Care Med 1996; 154: 24-29.

68. Peden DB, Boehlecke B, Horstman D, Devlin DB. Influx of bronchial neutrophils and eosinophils in asthmatics after prolonged exposure to $0.16 \mathrm{ppm}$ ozone. Am J Respir Crit Care Med 1996; 153: A700.

69. Adams WC, Schelegle ES. Ozone and high ventilation effects on pulmonary function and endurance performance. J Appl Physiol 1983; 55: 805-812.

70. Schelegle ES, Adams WC. Reduced exercise time in competitive simulations consequent to low level ozone exposure. Med Sci Sports Exerc 1986; 18: 408-414.

71. Foxcroft WJ, Adams WC. Effects of ozone exposure on four consecutive days on work performance and VO2max. J Appl Physiol 1986; 61: 960-966.

72. Folinsbee LJ, Bedi JF, Horvath SM. Pulmonary function changes after continuous heavy exercise in 0.21 ppm ozone. J Appl Physiol 1984; 57: 984-988.

73. Devlin RB, Folinsbee LJ, Biscardi F, et al. Attenuation of cellular and biochemical changes in the lungs of humans exposed to ozone for five consecutive days. Am Rev Respir Dis 1993; 147: A71.

74. Christian DL, Chen LL, Scannell CH, Ferrando RE, Welch BS, Balmes JR. Ozone-induced inflammation is attenuated with multi-day exposure. Am J Respir Crit Care Med 1996; 153: A699.

75. Stokinger HE, Wagner WD, Wright PG. Potentiating effects of exercise and tolerance development. Arch Ind Health 1956; 14: 158-162.

76. Hackney JD, Linn WS, Mohler J, Collier CR. Adaptation to short-term respiratory effects of ozone in men exposed repeatedly. J Appl Physiol 1977; 43: 82-85.

77. Horvath SM, Gliner JA, Folinsbee LJ. Adaptation to ozone: duration and effect. Am Rev Respir Dis 1981; 123: 496-499.

78. Farrell BP, Kerr HD, Kulle TJ, Sauder LR, Young JL. Adaptation in human subjects to the effects of inhaled ozone after repeated exposures. Am Rev Respir Dis 1979; 119: 725-730.

79. Folinsbee LJJ, Bedi JF, Horvath SM. Respiratory responses in humans repeatedly exposed to low concentrations of ozone. Am Rev Respir Dis 1980; 121: 431-439.

80. Yanai M, Ohrui T, Aikawa T, et al. Ozone increases susceptibility to antigen inhalation in allergic dogs. J Appl Physiol 1990; 68: 2267-2273.

81. McConnell R, Berhane K, Gilliland F, et al. Asthma in exercising children exposed to ozone: a cohort study. Lancet 2002; 359: 386-391.

82. Ball BA, Folinsbee LJ, Peden DB, Kehrl HR. Allergen bronchoprovocation of mild allergic asthmatics following ozone exposure. J Allergy Clin Immunol 1996; 98: 563-572.

83. Chen LL, Scannell CH, Tager I, et al. Effects of ozone on the response to inhaled antigen in allergic asthmatic subjects. Am J Respir Crit Care Med 1995; 151: A27.

84. Hazucha MJ, Ginsberg JF, McDonnell WF, et al. Effects of $0.1 \mathrm{ppm}$ nitrogen dioxide on airways of normal and asthmatic subjects. J Appl Physiol 1983; 54: 730-739.

85. Bauer MA, Utell MJ, Morrow PE, Speers DM, Gibb FR. Inhalation of $0.30 \mathrm{ppm}$ nitrogen dioxide potentiates exercise-induced bronchoconstriction in asthmatics. Am Rev Respir Dis 1986; 134: 1203-1208.

86. Linn WS, Shamoo DA, Avol EL, et al. Dose-response study of asthmatic volunteers exposed to nitrogen dioxide during intermittent exercise. Arch Environ Health 1986; 41: 292-296.

87. Moshenin V. Airway responses to nitrogen dioxide in asthmatic subjects. J Toxicol Environ Health 1987; 22: 371-380.

88. Roger LJ, Horstman DH, McDonnell WF, et al. Pulmonary function, airway responsiveness and respiratory symptoms in asthmatics following exercise in NO2. Toxicol Ind Health 1990; 6: 155-171.

89. Lebowitz MD, Holberg CJ, Boyer B, Hayes C. Respiratory symptoms and peak flow associated with indoor and outdoor air pollutants in the southwest. J Air Pollut Control Assoc 1985; 35: 1154-1158.

90. Goldstein IF, Lieber K, Andrews LR, et al. Acute respiratory effects of short-term exposures to nitrogen dioxide. Arch Environ Health 1988; 43: 138-142.

91. Tunnicliffe WE, Burge PS, Ayres JG. Effect of domestic concentrations of nitrogen dioxide on 
airway responses to inhaled allergen in asthmatic patients. Lancet 1994; 344: 1733-1736.

92. Sheppard D, Wong SC, Uehara CD, Nadel JA, Boushey HA. Lower threshold and greater bronchomotor responsiveness of asthmatic subjects to sulfur dioxide. Am Rev Respir Dis 1980; 122: 873-878.

93. Linn WS, Avol EL, Peng RC, Shamoo DA, Hackney JD. Replicated dose-response study of sulfur dioxide in normal, atopic and asthmatic volunteers. Am Rev Respir Dis 1987; 136: 1127-1134.

94. Horstman D, Roger LJ, Kehrl H, Hazucha MJ. Airway sensitivity of asthmatics to sulfur dioxide. Toxicol Ind Health 1986; 2: 289-298.

95. Balmes JR, Fine JM, Sheppard D. Symptomatic bronchoconstriction after short-term inhalation of sulfur dioxide. Am Rev Respir Dis 1987; 136: 11171121.

96. Reidel F, Kramer M, Scheibenbogen C, Rieger CHL. Effects of $\mathrm{SO} 2$ exposure on allergic sensitization in the guinea pig. J Allergy Clin Immunol 1988; 82: 527-534.

97. Churg A, Brauer M. Human lung parenchyma retains PM2.5. Am J Respir Crit Care Med 1997; 155: 2109_ 2111.

98. Brain JD, Valberg PA. Deposition of aerosol in the respiratory tract. Am Rev Respir Dis 1979; 120: 1325 1373.

99. Anderson M, Svartengren M, Philipson K, Camner P. Regional human lung deposition studied by repeated investigations. J Aerosol Sci 1994; 25: 567-581.

100. Salvi S, Holgate S. Mechanisms of particulate matter toxicity. Clin Exp Allergy 1999; 29: 1187-1194.

101. Seaton A, MacNee W, Donaldson K, Godden K. Particulate air pollution and acute health effects. Lancet 1995; 345: 176-178.

102. Smith KR, Aust AE. Mobilization of iron from urban particulates leads to generation of reactive oxygen species in vitro and induction of ferritin synthesis in human lung epithelial cells. Chem Res Toxicol 1997; 10: $828-834$.

103. Ghio AJ, Hatch GE. Lavage phospholipid concentration after silica instillation in the rat is associated with complexed $(\mathrm{Fe} 3+)$ on the dust surface. Am J Respir Cell Mol Biol 1993; 8: 403-407.

104. Donaldson K, Brown DM, Mitchell C, et al. Free radical activity of PM10: iron mediated generation of hydroxyl radicals. Environ Health Perspect 1997; 105: Suppl. 5, 1285-1289.

105. Costa DL, Dreher KL. Bioavailable transition metals in particulate matter mediate cardiopulmonary injury in healthy and compromised animal models. Environ Health Perspect 1997; 105: Suppl. 5, 1053-1060.

106. Dreher KL, Jaskot RH, Lehmann JR, et al. Soluble transition metals mediate residual oil fly ash induced acute lung injury. J Toxicol Environ Health 1997; 50: 285-305.

107. Costa DL, Lehmann JR, Winsett D, McGee J, Ghio A. Pulmonary toxicity of Utah valley PM: are empirical indices of adverse health effects coherent with the epidemiology? Am J Respir Crit Care Med 1998; 152: A880.

108. Diesel Working Group. Diesel exhaust, a critical analysis of emissions, exposure and health effects. Cambridge, MA, Health Effects Institute, 1995.

109. Sydbom A, Blomberg A, Parnia S, Stenfors N, Sandström T, Dahlén SE. Health effects of diesel exhaust emissions. Eur Respir J 2001; 17: 733-746.

110. Nauss KM, Busby WF Jr, Cohen AJ, . Critical issue in assessing the carcinogenicity of diesel exhaust: A synthesis of current knowledge. In: A Critical Analysis of Emission, Exposure and Health Effects. Health Effects Institutes Diesel Working Group. Diesel Exhaust. Cambridge, MA, Health Effects Institute, 1995; pp. 13-18.

111. Takafuji S, Suzuki S, Koizumi K, et al. Diesel-exhaust particulates inoculated by the nasal route have an adjuvant activity for IgE production in mice. J Allergy Clin Immunol 1987; 79: 639-645.

112. Takenaka H, Zhang K, Diaz-Sanchez D, Tsien A, Saxon A. Enhanced human IgE production results from exposure to the aromatic hydrocarbons from diesel exhaust: direct effects on B-cell IgE production. J Allergy Clin Immunol 1995; 95: 103-115.

113. Diaz-Sanchez D, Taieu A, Casillas A, Dotson AR, Saxon A. Enhanced nasal cytokine production in human beings after in vivo challenge with diesel exhaust particles. J Allergy Clin Immunol 1996; 98: 114-123.

114. Diaz-Sanchez D, Tsien A, Fleming J, Saxon A. Combined diesel exhaust particulate and ragweed allergen challenge markedly enhances human in vivo nasal ragweed-specific IgE and skews cytokine production to a $\mathrm{T}$ helper cell 2-type pattern. $J$ Immunol 1997; 158: 2406-2413.

115. Bayram H, Devalia JL, Sapsford RJ, et al. The effect of diesel exhaust particles on cell function and release of inflammatory mediators from human bronchial epithelial cells in vitro. Am J Respir Cell Mol Biol 1998; 18: 441-448.

116. Rudell B, Sandström T, Stjernberg N, Heldman KB. Controlled diesel exhaust exposure in an exposure chamber: pulmonary effects investigated with bronchoalveolar lavage. J Aerosol Sci 1990; 21: S411-S414.

117. Knox RB, Suphioglu C, Taylor P, et al. Major grass pollen allergen Lol $\mathrm{p} 1$ binds to diesel exhaust particles: implications of asthma and air pollution. Clin Exp Allergy 1997; 27: 246-251.

118. D'Amato G, Bonini S, Bosquet J, Durham SR, PlattsMills TAE. Pollenosis 2000: Global Approach. Naples, JGC Editions, 2001.

119. Burney PGJ, Malmberg E, Chinn S, Jarvis D, Luczynska C, Lai E. The distribution of total and specific serum $\operatorname{IgE}$ in the European Community Respiratory Health Survey. J Allergy Clin Immunol 1997; 99: 314-322.

120. Ishizaki $\mathrm{T}$, Koizumi $\mathrm{K}$, Ikemori $\mathrm{R}$, Ishiyama $\mathrm{Y}$, Kushibiki E. Studies of prevalence of Japanese cedar pollinosis among residents in a densely cultivated area. Ann Allergy 1987; 58: 265-270.

121. D'Amato G, Russo M, Liccardi G, et al. Comparison between outdoor and indoor airborne allergenic activity. Ann Allergy Asthma Immunol 1996; 77: 147153.

122. D'Amato G. Airborne paucimicronic allergen-carrying particles and seasonal respiratory allergy. Allergy 2001; 56: 1109-1111.

123. Wilson AF, Novey HS, Berke MD, Surprenant EL. Deposition of inhaled pollen and pollen extract in human airways. $N$ Engl J Med 1973; 288: 1056-1088.

124. Busse WW, Reed CE, Hoehne JH. Where is the allergic reaction in ragweed asthma? Demonstration of ragweed antigen in airborne particles smaller than pollen. J Allergy Clin Immunol 1972; 50: 289-285.

125. Solomon WR, Burge HA, Muilenberg ML. Allergen carriage by atmospheric aerosol. I. Ragweed pollen 
determinants in smaller micronic fractions. $J$ Allergy Clin Immunol 1983; 72: 443-447

126. Rantio-Lehtimaki A, Viander M, Koivikko A. Airborne birch pollen antigens in different particles. Clin Exp Allergy 1994; 24: 23-28.

127. Fernandez-Caldas E, Swanson MC, Pravda J, Welsh $P$, Yunginger JW, Reed CE. Immunochemical demonstration of red oak pollen aeroallergens outside the oak pollination season. Grana 1989; 28: 205-209.

128. Spieksma FTHM, Kramps JA, van Der Linden AC, et al. Evidence of grass-pollen allergenic activity in the smaller micronic atmospheric aerosol fraction. Clin Exp Allergy 1990; 20: 273-280.

129. Suphioglu C, Singh MB, Taylor P, Knox RB. Mechanism of grass pollen-induced asthma. Lancet 1992; 339: 569-572.

130. Packe GE, Ayres JG. Asthma outbreak during a thunderstorm. Lancet 1985; ii: 199-204.

131. Packe GE, Ayres JG. Aeroallergen skin sensitivity in patients with severe asthma during a thunderstorm. Lancet 1986; i: 850-851.

132. Bellomo R, Gigliotti P, Treloar A, Holmes P, Suphioglu C, Singh MB. Two consecutive thunderstorm associated epidemic of asthma in Melbourne. Med J Aust 1992; 156: 834-837.

133. Murray V, Venables K, Laing-Morton T, Partridge M, Williams D. Epidemic of asthma possibly related to thunderstorms. BMJ 1994; 309: 131-132.

134. Wallis DN, Davidson AC, Weilch $\mathrm{J}$, et al. Clinical and immunological characteristics of patients with thunderstorm asthma. Eur Respir J 1995; 8: 500s.

135. Davidson AC, Emberlin J, Cook AD, Venables KM and the Thames Regions Accident and Emergency Trainer Association. A major outbreak of asthma associated with a thunderstorm: experience of accident and emergency departments and patients characteristics. BMJ 1966; 312: 601-604.

136. Girgis ST, Marks GB, Downs SH, Kolbe A, Car GN, Paton R. Thunderstorm-associated asthma in an inland town in southeastern Australia. Who is at risk? Eur Respir J 2000; 16: 3-8.

137. Davis GL. The anther tapetum, Ubish granules and hay fever. Aust J Sci 1967; 30: 235-236.

138. D'Amato G. Immunological effects induced by biological natural aerosols (pollen and spores). $Z$ Erkrank Atm Org 1981; 157: 281-286.

139. Pacini E, Franchi GG. Role of the tapetum in pollen and spore dispersal. Plant Syst Evol 1993; 7: 1-11.

140. Vinckier S, Smets E. The potential role of orbicules as vector of allergens. Allergy 2001; 56: 1129-1136.

141. Miki-Hirosige H, Nakamura S, Yasueda H, Shida T, Takahashi Y. Immunocytochemical localization of the allergenic proteins in the pollen of Cryptomeria japonica. Sex Plant Reprod 1994; 7: 95-100.

142. Jensen J, Poulsen LK, Mygind N, Weeke ER. Immunochemical estimations of allergenic activities from outdoor aeroallergens, collected by a highvolume air sampler. Allergy 1989; 44: 52-59.

143. D'Amato G, Gentili M, Russo M, et al. Detection of Pajetaria judaica airborne allergenic activity: comparison between immunochemical and morphological methods including clinical evaluation. Clin Exp Allergy 1994; 24: 566-570.

144. Chapman MD. Allergens. In: Roitt IM, Delves PJ, eds. Encyclopedia of Immunology. London, Academic Press, 1998; pp. 64-69.

145. Price JA, Pollock I, Little SA, Longbottom JL, Warner JO. Measurement of airborne mite antigen in homes of asthmatic children. Lancet 1990; 336: 895897.

146. Antò JM, Sunyer J, Grimalt J, Aceves M, Reed CE. Outbreaks of asthma associated with soybean dust. N Engl J Med 1989; 320: 1097-1102.

147. Aceves M, Grimalt JO, Sunyer J, Antò JM, Reed CE. Identification of soybean dust as an epidemic asthma agent in urban areas by molecular marker and RAST analysis of aerosols. J Allergy Clin Immunol 1991; 88: 124-134.

148. Antò JM, Sunyer J, Reed CE, et al. Preventing asthma epidemics due to soybeans by dust control measures. $N$ Engl J Med 1993; 329: 1760-1763.

149. Hernando L, Navarro C, Màrquez M, Zapatero L, Galvañ F. Asthma epidemics and soybean in Cartagena (Spain). Lancet 1989; i: 502.

150. Garcia-Ortega P, Rovira E, Mora E. Soy-seed asthma epidemics in small cities. Med Clin 1997; 108: 677.

151. D'Amato G, Liccardi G, Cazzola M. Environment and development of respiratory allergy. I. Outdoors. Mon Arch Chest Dis 1994; 49: 406-411.

152. Salvaggio J, Hasselblad V, Seabury J, Heiderscheit LT. New Orleans asthma. II. Relationship of climatologic and seasonal factors of outbreaks. J Allergy 1970; 45: 257-265.

153. Salvaggio J, Seabury J, Schoenhardt EA. New Orleans asthma.v. relationship between Charity Hospital admission rates, semiquantitative pollen and fungal spore counts, and total particulate aerometric sampling data. J Allergy Clin Immunol 1971; 48: 96-114.

154. White MC, Etzel RA, Olson DR. Reexamination of epidemic asthma in New Orleans, Louisiana, in relation to the presence of soy at the harbor. $\mathrm{Am}$ $J$ Epidemiol 1997; 145: 432-438.

155. Garty BZ, Kosman E, Ganor E. Emergency room visits of asthmatic children, relation to air pollution, weather and airborne allergens. Ann Allergy Asthma Immunol 1998; 81: 563-570.

156. Schwartz J. Air pollution and daily mortality: a review and meta-analysis. Environ Res 1994; 64: 36-52.

157. Shumway RH, Azari AS, Pawitan Y. Modelling mortality fluctuations in Los Angeles as functions of pollution and weather effects. Environ Res 1988; 45: 224-241.

158. Emberlin J. The effects of air pollution on allergenic plants. Eur Respir Rev 1998; 53: 164-167.

159. Frenguelli $\mathrm{G}$, Bricchi E. The use of the pheno-climatic model for forecasting the pollination of some arboreal taxa. Aerobiologia 1998; 14: 39-44.

160. Ambiente Italia 2000. Rapporto sullo stato del Paese. Milan, Edizioni Ambiente, 2001.

161. Behrendt H, Becker WM, Friedrichs KH, Darson V, Tomingas R. Interaction between aeroallergens and airborne particulate matter. Int Arch Allergy Immunol 1992; 99: 425-428.

162. D'Amato G, Ruffilli A, Ortolani C. Allergenic significance of Parietaria (pellitory-of-the-wall) pollen. In: $\mathrm{D}^{\prime}$ Amato $\mathrm{G}$, Spieksma F, Bonini S, eds. Allergenic Pollen and Pollinosis in Europe. Oxford, Blackwell Scientific Publications, 1991; pp. 113-118. 